\title{
Cov-hep study: heparin in standard anticoagulation based on citrate for continuous veno-venous hemodialysis in patients with COVID-19: a structured summary of a study protocol for a randomized controlled trial
}

Paulo Ricardo Gessolo Lins* (D), Claudia Coimbra César de Albuquerque, Camila Fernandes Assis, Bruna Cristine Duarte Rodrigues, Beatriz Pinto e Siqueira Campos, Eduardo de Oliveira Valle, Carla Paulina Sandoval Cabrera, Jeison de Oliveira Gois, Gabriela Cardoso Segura, Fernando Louzada Strufaldi, Lorena Catelan Mainardes, Rayra Gomes Ribeiro, Daniela Del Pilar Via Reque Cortes, Luciana Gil Lutf, Márcia Fernanda Arantes de Oliveira, Gabriel Teixeira Montezuma Sales, Igor Smolentzov, Bernardo Vergara Reichert, Lucia Andrade, Victor Faria Seabra and Camila Eleuterio Rodrigues

\footnotetext{
Abstract

Objectives: The primary objective is to test if heparin added to a standard regional anticoagulation protocol based on citrate is able to reduce dialysis circuit losses by clotting without increasing the risk of thrombocytopenia or bleeding, in patients with COVID-19 with acute kidney injury requiring dialysis.

Trial design: Randomized, parallel-group, open-label trial, with two arms (ratio 1:1) comparing different continuous renal replacement therapy anticoagulation strategies.

Participants: Eligibility conditions:

All ICU patients of University of Sao Paulo General Hospital (Hospital das Clínicas), Brazil will be screened for eligibility conditions.

Adults (> 18 years old) with confirmed COVID-19 and acute kidney injury requiring dialysis with agreement between ICU and nephrology teams for the introduction of renal continuous replacement therapy in daily ICU rounds. Continuous renal replacement therapy will be prescribed by consulting nephrologists based on standard clinical guidelines, including acute kidney injury with hemodynamic instability plus hyperkalemia, severe acidosis, volume overload, respiratory distress, multiorgan failure or some combination of these factors.

(Continued on next page)
}

\footnotetext{
* Correspondence: paulo.lins@hc.fm.usp.br

niversity of São Paulo - Hospital de Clínicas, São Paulo, Brazil
}

C C The Author(s). 2020 Open Access This article is licensed under a Creative Commons Attribution 4.0 International License, which permits use, sharing, adaptation, distribution and reproduction in any medium or format, as long as you give appropriate credit to the original author(s) and the source, provide a link to the Creative Commons licence, and indicate if changes were made. The images or other third party material in this article are included in the article's Creative Commons. licence, unless indicated otherwise in a credit line to the material. If material is not included in the article's Creative Commons licence and your intended use is not permitted by statutory regulation or exceeds the permitted use, you will need to obtain permission directly from the copyright holder. To view a copy of this licence, visit http://creativecommons.org/licenses/by/4.0/. The Creative Commons Public Domain Dedication waiver (http://creativecommons.org/publicdomain/zero/1.0/) applies to the data made available in this article, unless otherwise stated in a credit line to the data. 


\section{(Continued from previous page)}

Data Collection:

Patients demographics and associated clinical data and comorbidities will be recorded at ICU entry.

Demographic information will include the patient's age, sex, and admission dates. Clinical data comprise comorbidities, APACHE 2, SAPS 3, need for mechanical ventilation, and use of vasopressor drugs.

Physiological data collected by the day of CRRT start will be vital signs, the arterial oxygen tension/fraction of inspired oxygen ( $\mathrm{PaO} 2 / \mathrm{FiO} 2)$ index, and serum creatinine, blood urea nitrogen, bilirubin, hemoglobin, hematocrit, platelets, white blood cell count levels and Peak D-dimer levels.

Patients will be analyzed for the first $72 \mathrm{~h}$ of CRRT, and they will be evaluated regarding clinical variables, filter patency and any adverse events that could be related to the anticoagulation choice, as bleeding (mild or major) or low platelets counts (<100.000 ui/uL) during treatment period. Mild and major bleeding will be defined by hemorrhagic event without clinical impact or hemoglobin ( $\mathrm{Hb}$ ) fall lesser than $1 \mathrm{~g} / \mathrm{dL}$ and hemorrhagic event with clinical impact or $\mathrm{Hb}$ fall higher than $1 \mathrm{~g} / \mathrm{dL}$, respectively.

Exclusion criteria:

Hypersensitivity to any of the substances going to be used in the study (Citric acid dextrosol $2.2 \%$ and unfractionated heparin); Previous diagnosis of coagulopathy or thrombophilia; Contraindication to the use of unfractionated heparin; Risk of citrate poisoning - (Lactate> $30 \mathrm{mg} / \mathrm{dL}$, international normalized ratio > 2.5, Total bilirubin> $15 \mathrm{mg} / \mathrm{dL}$ ); Pregnancy; Patients unlikely to survive for more than 24 hours.

The trial is being undertaken at the University of Sao Paulo General Hospital (Hospital das Clinicas), Brazil.

Intervention and comparator: Group A (control) - Patients on continuous renal replacement therapy (blood flow $150 \mathrm{ml} / \mathrm{min}$, dose of $30 \mathrm{~mL} / \mathrm{Kg} / \mathrm{h}$ ) receiving anticoagulation with sodium citrate at $4 \mathrm{mmol} / \mathrm{L}$

Group B (experiment): Patients on continuous hemodialysis (blood flow $150 \mathrm{~mL} / \mathrm{min}$, dose of $30 \mathrm{~mL} / \mathrm{Kg} / \mathrm{h}$ ) receiving anticoagulation with sodium citrate at $4 \mathrm{mmol} / \mathrm{L}$ associated with unfractionated heparin at $10 \mathrm{U} / \mathrm{Kg} / \mathrm{h}$.

Main outcomes: The percentage of clotted dialyzers within 72 hours in each of the studied groups (Primary outcome) Secondary outcomes: Number of dialyzers used in the first 72 hours of dialysis protocol, Mortality in the first $72 \mathrm{~h}$ of dialysis protocol, Bleeding events (Major or minor) in the first $72 \mathrm{~h}$ of dialysis protocol, Thrombocytopenia (less than 50.000 platelets) proportion in the first $72 \mathrm{~h}$ of dialysis protocol, Dialysis efficiency (Urea sieving) - variation in urea sieving between the first, second and third days of dialysis protocol, Continuous renal replacement therapy pressures (Arterial, Venous, dialysate and pre-filter pressure) in the first $72 \mathrm{~h}$ of dialysis protocol, in-hospital mortality.

Randomization: RedCap $\rightarrow$ randomization -2 blocks randomization by D-dimer level (5000ng/dL cut-off) and catheter site (Right Internal Jugular versus other sites) with 1:1 allocation ratio.

Blinding (masking): No blinding - Open label format

Numbers to be randomized (sample size): Total number of patients 90 (45 per group)

Trial Status: Trial version 2.0 - ongoing recruitment.

First recruitment: June 29, 2020

Estimated date for last recruitment: December 31, 2020

Trial registration: Responsible Party: University of Sao Paulo General Hospital (Hospital das Clinicas) ClinicalTrials.gov Identifier: NCT04487990, registered July 27, 2020, ReBec www.ensaiosclinicos.gov.br/rg/RBR-45kf9p/ Other Study ID Numbers: U1111-1252-0194

Full protocol: The full protocol is attached as an additional file, accessible from the Trials website (Additional file 1) In the interest in expediting dissemination of this material, the familiar formatting has been eliminated; this Letter serves as a summary of the key elements of the full protocol.

Keywords: COVID-19, Randomized controlled trial, protocol, Acute kidney injury, continuous dialysis, heparin, citrate, CWHD, CWHDF

\section{Supplementary information}

Supplementary information accompanies this paper at https://doi.org/10. 1186/s13063-020-04814-0.

Additional file 1. Full protocol
Acknowledgements

Not applicable

\section{Authors' contributions}

PRGL, CER, VFS and LA conceived and designed the study. MFAO, GTMS, IS, BVR verified the analytical methods. PRGL, CEL, VFS, LA, CCCA, CFA, BCDR, BPSC, EOV, CPSC, JOG, GCS, FLS, LCM, DPVRC, RGR, LGL discussed and 
revised the study protocol, and contributed to this final manuscript. The authors read and approved the final manuscript

\section{Funding}

This study was funded by Fundação Faculdade de Medicina (Clinics Hospital - University of São Paulo School Medicine Related Award) \#HCCOMVIDA. The funder had no role in the design and organization of the study; collection, management, analysis and interpretation of the data; preparation, analysis or approval of the manuscript; or decision to submit the manuscript for publication. The authors and their contributions to the manuscript are independent from the funder.

Availability of data and materials

All the Steering Committee members and co-authors will have access to the original dataset

The data will be available from the author on reasonable request by email.

\section{Ethics approval and consent to participate}

Ethics approval protocol - 33351120.0.0000.0068 (CAAE / CONEP / CEP) -

First approval on June 28, 2020 after initial submission on June 5, 2020. The authors certify that this trial has received ethical approval from the appropriate ethical committee as described above. All eligible patients receive written or recorded phone-call information about the study before giving their written or recorded phone-call informed consent to participate in the study.

\section{Consent for publication}

Not applicable.

\section{Competing interests}

CER reports receiving fees for medical teaching in catheter insertion from Medtronic. All other authors have nothing to disclose.

Received: 24 September 2020 Accepted: 16 October 2020

Published online: 11 November 2020

\section{Publisher's Note}

Springer Nature remains neutral with regard to jurisdictional claims in published maps and institutional affiliations.

Ready to submit your research? Choose BMC and benefit from:

- fast, convenient online submission

- thorough peer review by experienced researchers in your field

- rapid publication on acceptance

- support for research data, including large and complex data types

- gold Open Access which fosters wider collaboration and increased citations

- maximum visibility for your research: over $100 \mathrm{M}$ website views per year

At $\mathrm{BMC}$, research is always in progress.

Learn more biomedcentral.com/submissions 